\title{
corrigendum
}

\section{8 gendered embodiments: mapping the body-politic of the raped woman and the nation in Bangladesh}

Nayanika Mookherjee

Correction to: Feminist Review (2008) 88, 36-53.

doi:10.1057/palgrave.fr. 9400388

We regret that the author of the above article did not correctly cite the following reference:

Siddiqi, M.D. (1998) 'Taslima Nasreen and others' in Bodman, H. and Tohidi, N. (1998) editors, Women in Muslim Societies: Diversity within Unity, Boulder, CO: Lynne Rienner Publishers.

References to this work should also have been included on page 44 (final paragraph) and page 50 (first paragraph).

doi: $10.1057 /$ fr. 2011.32 